\title{
Kredi Temerrüt Swaplarının (CDS) Doğrudan Yabancı ve Portföy Yatırımları Üzerindeki Etkisi: Türkiye Örneği
}

Șener ILTER ${ }^{2}$ - Remzi GÖK ${ }^{3}$

Makale Gönderim Tarihi: 23 Aralık 2020

Makale Kabul Tarihi: 20 Ocak 2021

\section{Öz}

Bu çalıșmada 2005Q4 ve 2019Q3 periyodunda kredi temerrüt takasının (CDS) doğrudan yabancı (DY) ve portföy yatırımları (PY) üzerindeki etkileri incelenmiștir. Test sonuçlarına göre CDS oranlarındaki değișmeler ile diğer iki değișken arasında yüksek düzeyde anlamlı ve negatif, yatırım değișkenleri arasında ise $1 \%$ anlamlılık seviyesinde güçlü ve pozitif ilișki tespit edilmiștir. Ayrıca, DY değișkeninden CDS değișkenine doğru tek yönlü nedensellik bulunurken, CDS değișkeninin DY üzerinde herhangi bir nedensellik ilișkisine sahip olmadığı saptanmıștır. Diğer taraftan, CDS ve PY değișkenleri arasında $5 \%$ anlamlılık seviyesinde çift yönlü nedensellik bulgusuna rastlanmıștır. Test sonuçları hem finansal hem de iktisadi istikrarın/büyümenin sağlanmasında, politika karar alıcılarına önemli bilgi sunmaktadır.

Anahtar Sözcükler: CDS, DY, PY, Fourier Nedensellik.

JEL Sınıflandırması: F32; G1 1

1 Bu makale 15-17 Ekim 2020 tarihleri arasında Konya'da düzenlenen 4. Ekonomi Araștırmaları ve Finansal Piyasalar Kongresinde sözlü bildiri olarak sunulmuș ve kongre bildiri kitabında özeti yayınlanmıș bildirinin genișletilmiș halidir.

2 Araș. Gör., Anadolu Üniversitesi SBE, İktisat Bölümü, e-posta:iltersener@gmail.com; https://orcid.org/0000-0002-0255-2656

3 Araș. Gör., Dicle Üniversitesi İ̈BF, İșletme Bölümü, e-posta: remzi.gok@dicle.edu.tr; http://orcid.org/0000-0002-9216-5210 


\title{
The Impact of Credit Default Swaps (CDS) On Foreign Direct and Portfolio Investment: The Case of Turkey
}

\begin{abstract}
This paper investigates the effect of credit default swaps (CDS) on foreign direct (FDI) and portfolio investments (FPI) by using quarterly observations during the period 2005Q4-2019Q3 in Turkey. The findings indicate the changes in CDS correlate negatively with the FDI and FPI while the correlation coefficient between the last two variables is significantly positive at the $1 \%$ level. The changes in FDI Granger-cause the movements in CDS with no reverse direction. The test, however, detects a bidirectional causal relationship between the changes in FPI and CDS. The results yield important implications for sustainable financial stability and economic growth for policymakers.
\end{abstract}

Keywords: CDS, FDI, FPI, Fourier Causality.

JEL Classification: F32; G1 1

\section{Giriș}

24 Ocak 1980 kararları ile birlikte Türkiye'de ithal ikameci politikalardan vazgeçilerek serbest piyasa mekanizması benimsenmiștir. Bu kapsamda finansal piyasalarda da deregülasyon politikaları izlenerek sermaye hareketlerinin önündeki engeller așamalı olarak kaldırılmaya bașlanmıștır. Bu dönemde döviz kuru, faiz oranı, dıș ticaret ve yabacı sermaye politikalarında köklü değișikliklere gidilmiștir. Ayrıca Sermeye Piyasası Kanunu yenilenmiș, İstanbul Menkul Kıymetler Borsası ve Interbank kurulmuș ve Merkez Bankası açık piyasa ișlemlerine bașlamıștır. 1989 yılında çıkartılan Türk Parasının Kıymetini Koruma Hakkında 32 sayılı karar ve 1990 yılında Türk lirasının konvertibl olmasıyla tam anlamıyla finansal serbestleșme sağlanmıștır. Sermaye hareketlerinin önündeki engellerin kaldırılmasıyla birlikte 1990 yılından sonra zaman içinde Türkiye'de doğrudan yabancı ve portföy yatırımlarında ciddi artıșlar olmuștur. 1980'den sonra Türkiye, doğrudan ve dolaylı sermaye yatırımlarının önündeki engelleri kaldırarak yabancı sermayenin ülkeye gelmesini teșvik etmiștir. Türkiye'ye gelen yabancı yatırımlar cari açığın finansmanında, ekonominin üretim kapasitesinin artırılmasında, üretim 
ve istihdamın artırılmasında, yeni teknoloji ve yönetim bilgisi getirmesi gibi nedenlerden dolayı desteklenmektedir.

Bir firmanın üretimini, kurulu olduğu ülkenin dıșına tașıyarak farklı ülkelerde üretim tesisi kurması veya o ülkede bulunan üretim tesislerini satın alması doğrudan yabancı sermaye yatırımı olarak adlandırılmaktadır. Doğrudan yabancı sermaye yatırımları çok uluslu șirketler tarafından yapılmaktadır. Bu șirketler yabancı ülkede doğrudan sermaye yatırımı yaparken genellikle o ülkeye döviz transfer etmekle birlikte bazen de üretimde kullanmak için makine, donanım gibi fiziki üretim araçları ile lisans, teknik bilgi, know-how gibi maddi olmayan haklar ile giriș yaparlar. Dolaysız sermaye yatırımı yapan șirketler ülke dıșındaki tesisin mülkiyetine kısmen ya da tamamen sahip olur ve o tesisin yönetim veya denetimini ellerinde bulundururlar. Ülke dıșındaki ișletme ana șirketin sahip olduğu teknoloji, ticari sırlar, yönetim bilgileri ve öteki imkânlardan yararlanır ve karșılığında karın bir kısmını ya da tamamını, ham madde, yarı ișlenmiș veya mamul malları ana merkeze aktarırlar (Seyidoğlu, 2015, ss.649-651).

Portföy yatırımları; yabancı finansal kurumlar, kurumsal yatırımcılar ve bireysel yatırımcılar tarafından bir ülkenin borsasında ișlem gören hisse senetlerine, yatırım fonlarına, bono ve tahvil gibi finansal araçlarına yapılan kısa vadeli yatırımlardır (Karluk, 2013, s.757). Dolaylı yatırım veya sıcak para olarak da adlandıılan porfföy yatırımlarının amacı kısa sürede yüksek getiri elde etmektir. Dolayısıyla bir ülkede yatırım ortamını etkileyen ekonomik ve siyasi koșulların olumlu yönde seyretmesi ülkeye yapılan portföy yatırımlarını artırırken; beklentilerin olumsuz yönde seyretmesi ise ülkeden ani ve büyük miktarda sermaye çıkıșına neden olmaktadır. Portföy yatırımlarının bir ülkeyi ani ve büyük miktarlarda terk etmesi o ülkede yașanmakta olan krizi derinleștirmektedir.

Kredi Temerrüt Swapı (Credit Default Swap, CDS), borçlu tarafın borcunu ifa etmeme riskine karșılık alacaklı tarafından yapılan bir tür sigorta ișlemidir. Bu ișlemde sözleșme satın alan taraf, kredi temerrüt riskini üslenen karșı tarafa, sözleșme vadesi boyunca belirlenen tutarda prim öder. Diğer taraftan, sözleșmeyi satan taraf ise CDS ișlemine konu tutarın kısmen veya tamamen öden(e)memesi durumunda karșılașılan zararı ödemek zorundadır. Son küresel kriz döneminde 61.24 trilyon dolarlık bir piyasa hacmine ulașan CDS piyasası, 2017 yılının ikinci yarısında 9.35 trilyon doların alına inmiștir (Aldasoro ve Ehlers, 2018). 
Kredi derecelendirme kurulușlarının verdiği notların, ülke ve kurum risklerini sağlıklı bir șekilde yansıtamadığı ortaya çıkınca, yatırımcıların alternatif ürün arayıșları CDS piyasasının gelișiminde büyük rol oynamıștır. Kredi derecelendirme kurulușlarının belirli periyotlarda hizmet vermesi ve son küresel krizde görüldüğü üzere riskleri ölçmede yetersiz kalmaları, ayrıca risk seviyesindeki değișimlere yönelik anlık bilgi ihtiyacı, yatırımcıları CDS ürünlerini kullanmaya itmiștir. Bir ülkenin yurtiçi ve/veya yurtdıșı kaynaklı gelișmelere karșı, çeșitli sebeplerle, yüksek duyarlılık göstermesi, o ülkenin risk priminin diğer ülkelerin risk primlerine göre yüksek olması olasıdır. 2018 Ağustos ayında son on yılın en yüksek değerine ulașan $(576,62)$ Türkiye 5 yıllık CDS primi, 2020 yılının ilk ayında küresel ve yurtiçi gelișmelere paralel olarak 237.85 puana inse de küresel çapta etkisini sürdüren korona virüsü salgın endișesi, tarihi dip seviyelere inen ABD tahvil faizleri, 1700\$/ons fiyatına yaklașan altın fiyatları ve petrol fiyatlarında görülen büyük düșüșler nedeniyle tekrar yükselmeye bașlamıș, 9 Mart 2020'de 391.41 puandan kapanmıștır. Bu durum, aynı anda hem cari ve bütçe açığından hem de özel kesim tasarruf açığından mustarip olan Türkiye'nin benzer özelliklere sahip kırıgan ekonomiler listesinde en yüksek düzeyde yer alması hem doğrudan hem de dolaylı türden yabancı yatırımların ülkeye girișlerinin azalmasına ve/veya mevcut yatırımların çıkıșlarının artmasına sebep olmaktadır.

Bu çalıșmada Türkiye'nin kredi temerrüt swapları ile doğrudan yabancı sermaye yatırımları ve portföy yatırımları arasındaki ilișki, zaman serisi analizi kullanılarak incelenmiștir. Bu doğrultuda çalıșmamızda literatürde yer alan çalıșmalar özetlendikten sonra analizde kullanılan veri seti ve ekonometrik yöntemler tanıtılarak elde edilen bulgulara yer verilmiș ve sonuç ve öneriler sıralanmıștır.

\section{Literatür}

CDS primleri ile doğrudan ve portföy yatırımları arasındaki ilișkileri araștıran literatür incelendiğinde genellikle bu değișkenler ile birlikte farklı makroekonomik değișkenlerin kullandığı görülmektedir. Yapılan çalıșmalarda genellikle CSD primleri ile borsa endeksleri, hisse senedi piyasası, tahvil piyasası ve porfföy yatırımları değișkenleri arasındaki ilișki incelenmektedir. Yapılan çalıșmalar incelendiğinde benzer sonuçlar elde edildiği görülmektedir, yani CDS primi artınca, bu durum ülkeye gelen yabancı yatırımların azalmasına sebep olmaktadır. Yapılan çalıșmaların bir kısmında zaman serisi analizleri kullanılırken bir kısmında da panel veri analiz teknikleri kullanılmıștır. Bu çalıșmada doğrudan 
sermaye ve portföy yatırımları ile CDS primleri arasındaki ilișki zaman sersisi analizi kullanılarak incelenmektedir.

Çulha (2006), 1992M1-2005M12 dönemini kapsayan çalıșmasında, aylık veriler kullanılarak Türkiye'ye sermaye akıșını belirleyen itici ve çekici faktörlerin ne olduğunu yapısal vektör otoregresyon (SVAR) tekniği kullanılarak belirlemeye çalıșmıștır. Bu bağlamda yapılan çalıșma 1992 M1-2005M12 tüm dönem ve 1992M1-2001M12 ve 2002M12005M12 olmak üzere çalıșma iki alt dönemle ayrılmıștır. Etki tepi analizi sonuçlarına göre, tüm dönemde yurt içi faiz șokları Türkiye'ye yabanCı sermaye hareketlerini azaltırken, yurt dıș (ABD) faiz șoklarının yaban$\mathrm{Cl}$ sermaye hareketlerini artırdığı tespit edilmiștir. Bu durum 1990'larda ekonomide yașanan yüksek faiz ve yüksek enflasyon ile karakterize edilen istikrarsızlığa bağlanmaktadır. Öte yandan 2002M1-2005M12 döneminde ekonominin normalleștiği iç faiz șoklarının sermaye girișine neden olduğu ve dıș faiz șoklarının sermaye çıkıșına neden olduğu sonucuna varılmıștır. Ayrıca etki tepi analizi sonuçları, ABD sanayi üretim endeksinde meydana șoklar ile Türkiye'ye sermaye girișleri arasında pozitif ilișki olduğunu göstermektedir.

2001M1-2008M2 dönemine ait aylık verilerin kullanıldığı çalıșmada, Fung, Sierra, Yau ve Zhang (2008) üç Kuzey Doğu Asya ülkesi (Çin, Japonya ve Kore) ile dört Güneydoğu Asya ülkesinde (Endonezya, Malezya, Filipinler ve Tayland) CDS primleri ile hisse senedi fiyatları arasındaki ilișkiyi incelemișlerdir. Elde edilen bulgulara göre, Çin hariç diğer Asya ülkelerinde CDS primleri ve hisse senedi endeksi arasında yüksek, anlamlı ve negatif korelasyon olduğu tespit edilmiștir. Eșbütünleșme test sonuçlarına göre, Tayland, Kore ve Çin'de iki değișkenin uzun dönemde eșbütünleșik olduğu bulgusuna rastlanmıștır.

Ghosh ve Herwadkar (2009) tarafından yapılan çalıșmada 1998M04-2008M03 periyodunda aylık veriler kullanılarak küresel finansal krizden (KFK) önceki on yılda portföy hareketlerinin Hint finans piyasalarının çeșitli segmentleri üzerindeki etkisi analiz edilmiștir. Korelasyon analizi ve nedensellik testi sonuçları, portföy hareketlerinin hisse senedi fiyatlarında ve döviz kurlarında değișikliklere neden olduğunu göstermektedir. Kısa vadede, VAR ve etki tepki fonksiyonları net portföy hareketlerindeki pozitif bir șokun genellikle hisse senedi fiyatlarını artırdığı, döviz kurunu değerlendirdiği ve faiz oranlarını da düșürdüğünü göstermektedir. 
Norden ve Weber (2009), 2000-2002 dönemini kapsayan çalıșmalarında günlük, haftalık ve aylık verileri kullanarak CDS, tahvil ve hisse senedi piyasaları arasındaki ilișkiyi incelemișlerdir. Elde edilen bulgulara göre (i) hisse senedi piyasasındaki dalgalanmaların CDS ve tahvil marjlarını zıt yönde etkilediği, (ii) CDS primlerindeki değișmelerin tahvil piyasasını etkileme sayısının tahvil piyasasının CDS piyasasını etkileme sayısından daha fazla olduğu ve (iii) CDS piyasasının hisse senedine duyarlılık seviyesinin tahvil piyasasına göre daha yüksek olduğu sonucuna varılmıștır. Varlık fiyatlarının tespitinde, CDS piyasasının tahvil piyasasından daha yüksek katkıda bulunduğu ve bu katkının Avrupa menșeli firmalardan daha çok $A B D$ menșeli firmalardan sağlandığı tespit edilmiștir.

Ismailescu ve Kazemi (2010) tarafından yapılan bu çalıșmada, kredi derecelendirme notu ve kredi görünüm duyurularının 22 gelișmekte olan ülke CDS primleri üzerindeki etkisi incelenmiș ve CDS piyasalarının kredi derecelendirme olaylarına asimetrik reaksiyon gösterdiğine dair anlamlı sonuçlara ulașılmıștır. Illgili ülke notları ile ilgili sadece olumlu haberlerin CDS piyasaları üzerinde anlamlı etkiye sahip olduğu ve bu etkinin iki günlük periyotta diğer ülke piyasalarına da sıçradığı bulgusuna rastlanmıștır. Diğer taraftan kredi notlarına ilișkin olumsuz haberlerin, CDS piyasaları üzerinde hiçbir etkisinin olmadığı bulgusuna ulașılmıștır. Bu bulgu, gelișmekte olan ekonomilerdeki kredi yükseltmesinin kredi indirmesinden daha fazla bilgi tașıdığını düșündürmektedir. CDS primleri, negatif derecelendirme olayının olma olasılığını tahmin etmede yararlı bilgiler sağlarken, pozitif derecelendirme olayının olma olasılığını tahmin edememektedir. Bu bulgunun önemli bir sonucu, CDS primlerini kullanarak piyasa katılımcılarının, gelișmekte olan piyasalarda kredi kalitesindeki olumsuz değișiklikler hakkında tahminler elde edebilmeleridir.

1977M01-2007M12 dönemine ait aylık frekanstaki verilerin kullanıldığı çalıșmada, Egly, Johnk ve Liston (2010) net yabancı portföy yatırım girișlerinin yatıımcı riskten kaçınma ve ABD borsası üzerine etkisini incelemișlerdir. VAR modelinin kullanıldığı bu araștırmaya göre, borsaya yönelik olumlu șokların net kurumsal bono akımı üzerinde anlamsız ancak net kurumsal hisse senedi akımı üzerinde ise kısa vadeli ve anlamlı pozitif tepki verdiği sonucuna ulașılmıștır. Diğer taraftan, riskten kaçınma faktöründeki değișmelerin net kurumsal hisse yatırımları üzerindeki etkisinin istatistiksel olarak anlamsız, net kurumsal tahvil yatırımları üzerinde ise orta vadede geçerli anlamlı bir etki bıraktığı tespit 
edilmiștir. Yazarlar (2010), ülkeye özgü iç faktörlerin yabancı porfföy girișlerini etkileyebileceği sonucuna ulașmıșlardır.

Türkiye'ye yönelik 1989-2011 döneminde yapılan sermaye akımlarının hacmi ve kompozisyonun incelendiği çalıșmada, Karahan ve İpek (2013) finansal yatıııların toplam yatııılardaki payının yüksek olduğunu ve oldukça oynak ve dalgalı seyir izleyen bu tür spekülatif yatııımlarının, Türkiye ekonomisinin krizlere karșı kırılganlığını artırdığını gözlemlemișlerdir.

Hancı (2014) Ocak 2008-Aralık 2012 dönemine ait günlük Bist 100 ve CDS primlerini kullanarak değișkenler arasındaki olası ilișkinin varlığı, yönü ve derecesini araștırmıștır. Elde edilen bulgulara göre her iki değișken arasında negatif yönlü bir ilișkinin olduğu tespit edilirken, değișkenler arasındaki volatilitenin çok yüksek ve șokların dirençli çıkığı ve ortalamaya geri dönüșlerin zaman aldığı sonucuna varılmıștır.

JP Morgan EMBI endeksine dâhil olan, Türkiye'nin de aralarında olduğu 12 gelișmiș ülkeye ait CDS primleri ile borsa endeksi ve döviz kuruna ait aylık gözlemlerin kullanıldığı bir çalıșmada, Bașarır ve Keten (2016) değișkenler arasındaki kısa ve uzun dönemli potansiyel ilișkiyi araștırmıștır. Panel eșbütünleșme test sonuçlarına göre değișkenlerin uzun dönemde birlikte hareket ettikleri saptanmasına rağmen, herhangi bir nedensellik bulgusuna rastlanmamıștır. Diğer taraftan, 2010-2016 döneminde, CDS ve borsa endeksi arasında geçerli çiff yönlü, CDS primlerinden döviz kuruna doğru \%10 anlamlılık düzeyinde tek yönlü nedensellik bulunmuștur.

2010-2015 dönemine ait günlük frekanstaki verilerin kullanıldığı çalıșmada, Değirmenci ve Papuçcu (2016) BIST100 endeksi ve Türkiye'nin 5 yıllık CDS primleri arasındaki ilișkiyi, etki-tepki analizi, Granger nedensellik testi ve yapay sinir ağı tabanlı, doğrusal olmayan otoregresif (NARX) modeller kurularak incelemișlerdir. Etki-tepki analizine göre değișkenlerin volatilitesinde en büyük payın ilgili değișkene ait șoklara ait olduğu gözlenmiștir. Granger nedensellik test sonuçlarına göre her iki değișken arasında çift yönlü bir ilișkinin varlığı tespit edilmiștir. Nedensellik sonuçlarına göre olușturulan NARX modeli, borsa endeksine ait değișmelerin CDS primlerinin tahmininde güçlü ve anlamlı bir etkiye sahip olduğu bulgusuna rastlanmıștır.

Caporale, Ali, Spagnolo ve Spagnolo (2017), Ocak 1993-Kasım 2012 dönemine ait aylık gözlemdeki verileri kullanarak kısa vadeli (his- 
se senedi ve tahvil) portföy yatırımlarının döviz kuru oynaklığı üzerine etkisini, $A B D$ ve Asya'nın sekiz gelișen ve gelișmekte olan ülkesinde (Hindistan, Endonezya, Güney Kore, Pakistan, Hong Kong, Tayland, Filipinler ve Tayvan) araștırmıșlardır. Döviz kuru oynaklığını modellemek için MARKOV rejim değișim modelinin kullanıldığı çalıșmada, net kısa vadeli portföy girișlerinin döviz kuru oynaklığını artırdığı tespit edilmiștir. Özellikle net tahvil girișlerinin Pakistan, Tayland ve Filipinler piyasasında döviz kuru oynaklığının düșük düzeyde kalma olasılığını artırdığı; Endonezya'da ise döviz kurunun daha yüksek düzeyde oynak kalmasına neden olduğu sonucuna varılmıștır. Ayrıca Hindistan, Endonezya, Güney Kore, Hong Kong ve Tayvan'dan ABD'ye net sermaye girișinin oynaklığın yüksek düzeyde kalma olasılığını artırdığı saptanmıștır.

Çonkar ve Vergili (2017), tarafından yapılan çalıșmada, 4 Ocak 2010-31 Ağustos 2015 dönemini kapsayan günlük veri seti kullanılarak Türkiye'nin CDS primleri ile Dolar/TL kuru ve Euro/TL kuru arasındaki ilișkinin yönü ve derecesi araștırılmıștır. Yapılan test sonuçlarına göre değișkenler arasında herhangi bir uzun dönemli ilișki bulunmazken; Dolar/TL kuruna ait gecikmeli değerlerin CDS primlerinin cari değerleri üzerinde 5\% anlamlılık düzeyinde anlamlı bir etkisinin olduğu tespit edilmiștir.

Alıntaș ve Okuyan (2019) Türkiye'nin de aralarında bulunduğu bir grup ülkeye ait büyüme oranlarının CDS primlerinden etkilenip etkilenmediği konusu incelenmiștir. Üçer aylık verilerin kullanıldığı bu çalıșmada, Türkiye, Arjantin ve Mısır için çift taraflı, Katar ve Pakistan için büyüme oranlarından CDS primlerine doğru tek yönlü nedensellik bulgusuna rastlanmıștır. Diğer taraftan, Danacı vd. (2017) tarafından 2009-2015 periyodu için geçerli iki değișken arasında çift yönlü nedensellik sonucu elde edilmiștir.

Politik risklerin doğrudan yabancı yatırımların üzerindeki etkisini inceleyen Benghoul (2019), bașta düzenleyici kalite ve hükümet etkinliği gibi faktörlerin Tunus'ta doğrudan yabancı yatırımların üzerinde kritik öneme sahip olduğu sonucuna ulașmıștır. Yazar (2019), siyasi risklerin ve belirsizlikleri azaltılması ve yabancı yatırımcıların teșvik edilmesi ve Tunus siyasi sistemine olan güvenlerini korunması yatırım politikalarının güncellemesinin son derece gerekli olduğunu belirtmektedir. Benzer değișkenler arasındaki ilișkiyi Türkiye örneğinde inceleyen Gokmenoglu, Kirikkaleli ve Eren (2019) ise, ekonomik riskteki değișmelerin, doğrudan yabancı yatırım girișlerinde önemli değișikliklere yol açı̆̆ı sonucuna 
ulașmıștır. Diğer bir ifadeyle, ekonomik risk değișkeninden doğrudan yabancı yatırımlara doğru tek yönlü nedensellik kanıtı elde etmiștir. Kronik cari açık sorunu, yüksek enflasyon ve düșük kredi notları yüzünden ekonomik risk düzeyi artan ülkede, politika yapıcılarının iktisadi faaliyetlere katılımı teșvik etmek için belirleyici para ve maliye politikaları uygulamaları gerektiğini, ayrıca çok uluslu șirketlere yatırım kolaylığı, kurumsal vergi ve sübvansiyonlu krediler gibi ek teșviklerin verilmesi ileri sürmüșlerdir.

Sadeghzadeh (2019), panel veri analizi yöntemini kullanarak ABD, Fransa, İngiltere, Japonya, Çin, G. Kore ve Türkiye'nin beș yıllık CDS primleri ile borsa endeksleri arasındaki ilișkiyi incelemiștir. Test sonuçlarına göre, $A B D$ ve İngiltere'de CDS ve borsa endeksleri arasında herhangi bir anlamlı eșbütünleșme ilișkisi bulunamazken; Fransa, Japonya, Çin ve Türkiye'de risk primindeki artıșın borsa endeksini zıt yönde, G. Kore'de ise aynı yönde etkilediği tespit edilmiștir.

Yıldırım ve Sakızcı (2019), 2010Q1-2018Q3 periyodunda yer alan çeyreklik verileri kullanarak Türkiye'de CDS primleri ile portföy yatırımları arasındaki ilișkiyi zaman serisi analizi aracılığıyla incelemișlerdir. Yapılan ARDL sınır test sonucuna göre, iki değișkenin kısa dönemde zıt yönde hareket ettiği ancak ilișkinin uzun dönemde geçerli olmadığı bulgusuna rastlanmıștır. Diğer taraftan, CDS primlerinden portföy yatırımlarına doğru tek yönlü nedensellik ilișkisi olduğu saptanmıștır.

\section{Veri ve Metodoloji}

\subsection{Veri}

Bir ülkenin risk priminde meydana gelen değișmeler o ülkeye yatırım yapan yabacı yatırımcılarının tercihini etkilemektedir. Ülkenin risk priminde meydana gelen atıș o ülkeye yatırım yapma isteğini azalıırken, risk priminde meydana gelen azalıș ise o ülkeye yatırım yapma isteğini artırmaktadır. Bu çalıșmada da doğrudan yabacı sermaye yatırımları ve portföy yatırmaları ile CDS primleri arasında ilișkiler ekonometrik yönden incelenmektedir. Bu doğrultuda 2005Q4-2019Q3 dönemini kapsayana 56 çeyreklik veri seti kullanılmıștır. Doğrudan yabancı sermaye yatırımları, portföy yatırımları ve CDS primleri Amerikan Doları cinsinden hesaplanmıștır. CDS verileri Bloomberg terminalinden diğer değișkenler ise TCMB EDVS'den alınmıștır. Çalıșmada kullanılan zaman serilerinin logaritması alınmıș ve uygulama kısmında Eviews ve Gauss paket programları kullanılmıștır. 
Zaman serileri ile yapılan çalıșmalarda elde edilen bulguların güvenilir sonuçlar vermesi için kullanılan serilerin birim kök içermemesi gerekir. Bu kapsamda çalıșmada kullanılan serilerin birim kök içerip içermediğini tespit etmek için Fourier ADF birim kök testi kullanılmıștır. Enders ve Lee (2012) tarafından geliștirilen birim kök testi birden fazla yapısal değișimin düșük frekanslı Fourier fonksiyonlarıyla tahmin edilmesine olanak sağlamaktadır. Bu birim kök testinde diğer birim kök testlerinin aksine yapısal değișimin sayı ve konumunun bilinmesine gerek yoktur. İlerleyen așamada değișkenler arsındaki ilișkileri tespit etmek amacı ile Fourier Granger nedensellik testi kullanılmıștır.

2007 yılının ikinci yarısında bașlayan ve 2009 yılının ilk yarısında etkisi azalmaya bașlayan küresel finansal kriz (KFK) döneminde, Türkiye'nin CDS primleri artarak 400 baz puanın üzerine çıkmıș ve krizin etkisi azalmaya bașlaması ile birlikte CDS primleri azalmaya bașlamıș ve krizden önceki seviyelere dönmüștür. Ayrıca kriz döneminde Türkiye'de hem doğrudan sermaye yatırımları hem de portföy yatırımları krizin bașlamayla birlikte düșmeye bașlamıș ve krizin etkilerinin hafiflemeye bașlamasıyla hem doğrudan sermaye yatırımları hem de portföy yatırımları artmaya bașlamıștır. 2009'un sonunda bașlayan ve 2012 yılının ikici yarısına kadar devam eden Avrupa Borç Krizi (İrlanda, İspanya, İtalya ve Yunanistan), Türkiye'de CDS primleri, doğrudan sermaye yatırımları ve portföy yatırımları üzerinde fazla bir etki yaratmamıștır. Bu dönemde CDS primleri bir miktar artarken, doğrudan sermaye yatırımlarında da artıș gözlemiș ve porfföy yatırımları ise kriz boyunca belli bir düzeyde seyretmiștir. Türkiye'de meydana gelen siyasi ve ekonomik gelișmeler neticesinde 2018 yılının ağustos ayında Türkiye'de kur krizinin yașanmasına neden olmuștur. 2018 yılının bașından beri Türkiye'nin CDS primleri artıș gösterirken, doğrudan sermaye yatırımları ve portföy yatırımları ise azalmaya bașlamıștır. Bu dönemde ülkenin CDS primleri Küresel Finans Krizi'ndeki seviyelere yükselmiș ve doğrudan sermaye yatırımları ile porfföy yatırımları da 2018 öncesine göre düșüș göstermiștir. 
Șekil 1: 2005Q4-2019Q3 Dönemi CDS, DY ve PY Serileri
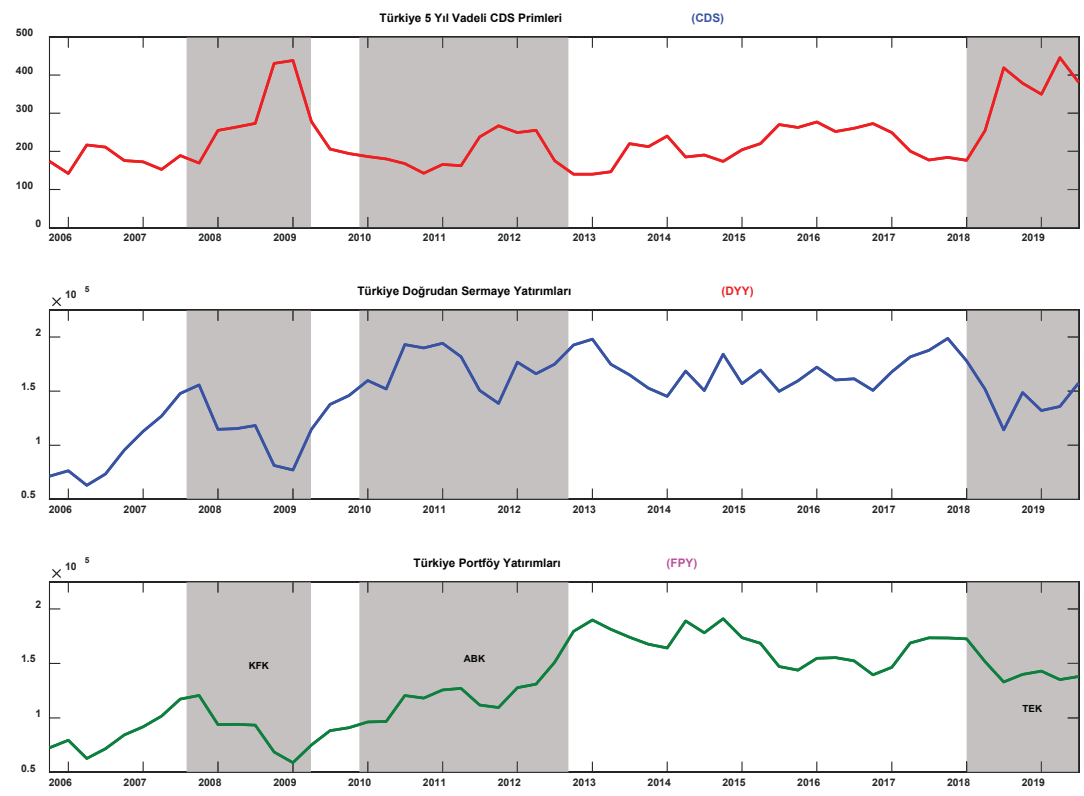

KFK: Küresel Finans Krizi [2007 Ağustos - 2009 Mart], ABK: Avrupa Birliği Borç Krizi [2009 Kasım - 2012 Eylül], TEK: Türkiye Ekonomik Krizi [2018 Ocak - 2019Q3]

\subsection{Metodoloji}

\subsubsection{Enders ve Lee (2012) Fourier ADF Birim Kök Testi}

Araștırma kapsamında yer alan değișkeneler arasındaki ilișkiyi incelemede yapılan ilk adım olan birim kök testi için Enders ve Lee (2012) tarafından ortaya atılan Fourier fonksiyonlarına dayanan Fourier ADF (FADF) tipi birim kök testi kullanılmıștır. Bu testte, FADF fonksiyonuna ait bir frekans bileșeni kullanılarak modelin deterministtik bileșeni tahmin edilebilmektedir. Tahmin sürecinde çoklu yapısal kırılmaları elde etmek için doğrusal olmayan yöntemin izlenmesiyle birlikte, modele kukla değișkenlerin eklenmesi durumunda yașanacak, olası güç kaybından kaçınılmaktadır. Lagrange çarpanı (LM) metodolojisine dayanan bu teste ilk așamada așağıdaki birinci farkı alınmıș model tahmin edilmektedir:

$$
\Delta y_{t}=\theta_{0}+\theta_{1} \Delta \sin \left(\frac{2 \pi k t}{T}\right)+\theta_{2} \cos \left(\frac{2 \pi k t}{T}\right)+u_{t}
$$


1 no'lu denklemde elde edilen tahmini katsayıların $\tilde{\theta}_{0}, \tilde{\theta}_{1}$, ve $\tilde{\theta}_{2}$ olarak belirlenmesinden sonra trendden arındırıııș așağıdaki serileri tahmin așamasına geçilmektedir:

$$
\widetilde{M}_{t}=y_{t}-\tilde{\delta}-\tilde{\theta}_{0} t-\tilde{\theta}_{1} \sin \left(\frac{2 \pi k t}{T}\right)-\tilde{\theta}_{2} \cos \left(\frac{2 \pi k t}{T}\right), \quad t=2, \ldots, T
$$

Daha sonra, trendden arındırılmıș seriler kullanılarak așağıda ki model olușturulur:

$$
\Delta y_{t}=R \tilde{M}_{t-1}+h_{0}+h_{1} \Delta \sin \left(\frac{2 \pi k t}{T}\right)+h_{2} \cos \left(\frac{2 \pi k t}{T}\right)+\varepsilon_{t}
$$

3 no'lu denklemde $t$ trendi, $k$ frekansı, $T$ örneklem sayısını ifade etmektedir. Burada her bir $k=1, \ldots, 5$ için model tahmin edilirken, en küçük kalıntı kareler toplamını veren $k$ değerinin optimal frekans boyutu olduğuna karar verilir. Uygun modeldeki hata terimine ait kalıntıların otokorelasyon içerip içermediği test edilir. $R=0$ olması durumunda $y_{t}$ değișkeninin durağan olmadığı sonucuna varılırken yukarıdaki modele $\widetilde{M}_{t}$ parametresinin gecikmeli değerleri eklenir:

$$
\Delta y_{t}=R \widetilde{M}_{t-1}+h_{0}+h_{1} \Delta \sin \left(\frac{2 \pi k t}{T}\right)+h_{2} \cos \left(\frac{2 \pi k t}{T}\right)+\sum_{j=1}^{p} \widetilde{M}_{t-j}+\varepsilon_{t}
$$

Testin son așamasında sıfır hipotezi, $\theta_{0}=\theta_{1}=0, k$ frekanslı doğrusal olmayan trende sahip alternatif hipoteze karșı test edilir. Eğer $F(k)$ istatistik değerleri yeterince büyükse, diğer bir ifadeyle sıfır hipotezi reddedilirse, doğrusal olmayan FADF testi $\left(\tau_{L M}\right)$, aksi durumda ise standart ADF testi kullanılır.

\subsubsection{Fourier Granger Nedensellik Testi}

Mısır ve petrol piyasaları arasındaki ilișkiyi inceledikleri çalıșmada, Enders ve Jones (2016) așağıdaki VAR modelini tahmin etmișlerdir:

$$
z_{t}=\gamma+\sum_{i=1}^{11} B_{i} z_{t-i}+e_{t}
$$

Denklemde $\gamma$ parametresi sabit katsayıları gösteren (4x1) vektörü, $B_{i}(4 \mathrm{x} 4)$ katsayı vektörü ve $e_{t}$ ise değișmeleri temsil eden dik vektörü temsil etmektedir.

Yapılan etki-tepki analiz sonuçları makul bulunsa da yazarlar (2016) iki önemli sorun bulunduğu belirtmektedirler. İlk sorun, olası yapısal kırılmaların dâhil edilmemesi nedeniyle 5 no'lu denklemde yer alan sistemin yanlıș tanımlanmıș olmasından kaynaklanmaktadır. İkincisi, kısıtsız VAR modelinin gereğinden fazla parametre barındırması, güven aralıklarının gereksiz yere geniș olmasına yol açacaktır. Yazarlar 
(2016), dolayısıyla, deterministtik regresörlerin așağıdaki gibi belirlenmesini önermektedirler:

$$
\begin{gathered}
z_{t}=\gamma(t)+\sum_{i=1}^{11} B_{i} z_{t-i}+e_{t} \\
\gamma(t)=\left[\gamma_{1}(t), \gamma_{2}(t), \gamma_{3}(t), \gamma_{4}(t)\right]^{\prime}
\end{gathered}
$$

7 no'lu denklemde yer alan her bir sabit $\gamma_{i t}$ parametresinin denklemdeki gibi $n$ adet Fourier frekansına bağlı olduğunu düșünürsek

$$
\gamma_{i}(t)=\varphi_{i}+\mu_{i} t+\sum_{k=1}^{n} \varphi_{i k} \sin \left(\frac{2 \pi k t}{T}\right)+\mu_{i k} \cos \left(\frac{2 \pi k t}{T}\right)
$$

modeli elde edilecektir. Bu modele yapısal kırılmaları temsilen Fourier terimlerinin kullanılması, yazarlara (2016) göre değișkenler arasında daha güçlü ilișkinin tespit edilmesiyle sonuçlanmaktadır.

\section{Bulgular}

Bu bölümde, araștırma kapsamındaki değișkelere ait tanımlayıcı istatistik bilgileri ile değișkenlerin birim kök içerip içermediğini sınamak için kullanılan Fourier ADF birim kök testi ve değișkenler arasındaki ilișkinin yönünü belirlemek için kullanılan Fourier Granger nedensellik testine ait analiz sonuçları yer almaktadır.

Tablo 1: Tanımlayıcı İstatistik

\begin{tabular}{lccc}
\hline Değișkenler $(\% \Delta)$ & CDS & FDI & FPI \\
\hline Ortalama & 1.4275 & 1.4371 & 1.1674 \\
Medyan & -2.036 & 2.766 & 1.1378 \\
Maksimum & 49.8307 & 39.6685 & 24.346 \\
Minimum & -45.4951 & -37.4103 & -30.67 \\
Standart Sapma & 20.6996 & 15.079 & 11.3488 \\
Çarpıklık & 0.4919 & -0.1269 & -0.472 \\
Basıklık & 3.1774 & 3.1776 & 3.3965 \\
Normal Dağılım (JB) & 2.29 & 0.22 & 2.4 \\
Gözlem Sayısı & 55 & 55 & 55 \\
\hline
\end{tabular}

Tablo 1'de Türkiye'de CDS primi, yabancı doğrudan sermaye yatırımları ve portföy yatırımları arasındaki ilișkiler test edilmeden önce bu değișkenlere ait temel istatistiki göstergeler incelenmiș ve yorumlanmıș- 
tır. İncelenen dönemde CDS primi maksimum değere 2018Q3 periyodunda, 2009Q2 periyodunda ise en düșük değere ulașmıștır. Doğrudan sermaye yatırı maksimum değere 2008Q4 çeyreğinde maksimum değere ulașmıș ve 2009Q2 çeyreğinde minimum değere ulașmıștır. Portföy yatırımları ise doğrudan sermaye yatırımları ile benzer dönemlerde maksimum ve minimum değerlere ulașmıștır. Değișkenler arasındaki ilișkilerin incelendiği bu dönemde CDS primi serisinin standart sapmasının diğer seriler göre yüksek olması bu serinin oynaklığının diğer serilerin oynaklığından yüksek olduğunu göstermektedir. JB normallik test sonucuna göre serilerin tamamı normal dağılıma sahiptir.

Tablo 2: Fourier ADF Birim Kök Test Sonuçları

\begin{tabular}{|c|c|c|c|c|c|c|}
\hline \multirow[b]{2}{*}{ Düzey (Log) } & \multicolumn{3}{|c|}{ Sabit } & \multicolumn{3}{|c|}{ Sabit ve Trend } \\
\hline & Gecikme & Fourier(k) & T-ístatistik & Gecikme & Fourier(k) & T-İstatistik \\
\hline CDS & 2 & 1 & -3.077 & 2 & 1 & -3.711 \\
\hline FDI & 5 & 4 & $-2.728^{*}$ & 3 & 1 & $-5.262 * * *$ \\
\hline \multirow[t]{2}{*}{ FPI } & 5 & 1 & -3.911 ** & 3 & 1 & -4.378 ** \\
\hline & \multicolumn{3}{|c|}{ Sabit } & \multicolumn{3}{|c|}{ Sabit ve Trend } \\
\hline Birinci Fark & Gecikme & Fourier & T-İstatistik & Gecikme & Fourier & T-İstatistik \\
\hline CDS & 3 & 4 & $-4.524 * * *$ & 3 & 4 & $-4.518 * * *$ \\
\hline FDI & 5 & 4 & $-4.325^{* * *}$ & 5 & 4 & $-4.576^{* * *}$ \\
\hline FPI & 4 & 1 & $-4.497 * * *$ & 4 & 2 & $-4.444^{* *}$ \\
\hline
\end{tabular}

Not: ${ }^{* * *},{ }^{* *}$ ve ${ }^{*}$ sırasıyla \%1, \%5 ve \%10 düzeyinde istatistiksel olarak anlamlılığı ifade etmektedir. Kritik değerler Enders ve Lee (2012), çalıșmasından elde edilmiștir.

Tablo 2'de Fourier ADF birim kök test sonuçları yer almaktadır. Fourier ADF birim kök testi sonuçlarına göre, düzey değerlerinde, sabit modelde FDI serisi \%10 önem düzeyinde, FPI serisi ise \%5 önem düzeyinde durağan iken sabit ve trendli modelde FDI serisi \% 1 önem düzeyinde, FPI serisi ise yine \%5 önem düzeyinde durağandır. CDS serisi ise hem sabit hem de sabit ve trendli modelde birim kök içermektedir. Serilerin birinci farkları alındıktan sonra yapılan testlerde ise serinin birim kök içerdiğini ifade eden boș hipotez reddedilerek serilerin durağan I(1) olduğunu ifade eden alternatif hipotez kabul edilmiștir. Çalıșmada kullanılan CDS, FDI ve FPI serilerinin tümü birinci farkı alındığında durağan hale gelmektedir. 
Tablo 3: Fourier Granger Nedensellik Testi Sonuçları

\begin{tabular}{|c|c|c|c|c|c|c|c|c|c|}
\hline & & & \multirow{2}{*}{$\begin{array}{l}\text { Optimal } \\
\text { Gecikme }\end{array}$} & \multirow{2}{*}{$\begin{array}{l}\text { Optimal } \\
\text { Frekans }\end{array}$} & \multirow{2}{*}{$\begin{array}{l}\text { Asimptotik } \\
\text { Test İstatistiği }\end{array}$} & \multirow{2}{*}{$\begin{array}{l}\text { Boostrap } \\
\text { Test İstatistiği }\end{array}$} & \multicolumn{3}{|c|}{ Kritik Değerler } \\
\hline & & & & & & & $\% 10$ & $\% 5$ & $\% 1$ \\
\hline DL_CDS & $\nRightarrow$ & DL_FDI & 5 & 3 & 1.559 & 1.559 & 10.099 & 12.312 & 18.137 \\
\hline DL_FDI & $\nRightarrow$ & DL_CDS & 5 & 3 & 11.368 ** & $11.368 *$ & 10.054 & 12.349 & 18.511 \\
\hline DL_CDS & $\nRightarrow$ & DL_FPI & 2 & 3 & $8.09 * *$ & $8.09 * *$ & 4.809 & 6.453 & 10.523 \\
\hline DL_FPI & f & DL_CDS & 2 & 3 & $8.103^{* *}$ & $8.103^{* *}$ & 4.868 & 6.594 & 10.624 \\
\hline
\end{tabular}

Not: ${ }^{* *},{ }^{* *}$ ve ${ }^{*}$ sırasıyla \% 1, \%5 ve \%10 düzeyinde istatistiksel olarak anlamlılığı ifade etmektedir.

Tablo 3, Enders ve Jones (2016) Fourier Granger nedensellik test sonuçlarını göstermektedir. Analiz bulgularına göre, DL_CDS ve DL_FPI değișkenleri arasında \%5 anlamlılık düzeyinde çift yönlü nedensellik bulunmakładır. Buna göre, her bir değișkene ait cari değerlerin modele dâhil edilmesiyle, diğerinin gelecekteki değerini tahmin etmek olasıdır. Diğer taraftan, DL_CDS ve DL_FDI değișkenleri arasındaki nedenselliğin yönü ise, doğrudan yabancı yatırımlardaki değișmeden CDS primlerindeki değișmeye doğru gerçekleșmiștir. Bulgular, Fung vd. (2008), Değirmenci ve Papuçcu (2016) ve Yıldııım ve Sakızcı'nın (2019) çalıșmalarında elde ettiği sonuçlar ile paralellik göstermektedir.

Șekil 2: Getiri Değișkenleri Arasındaki Zamanla Değișen Korelâsyon Iliş̦isi
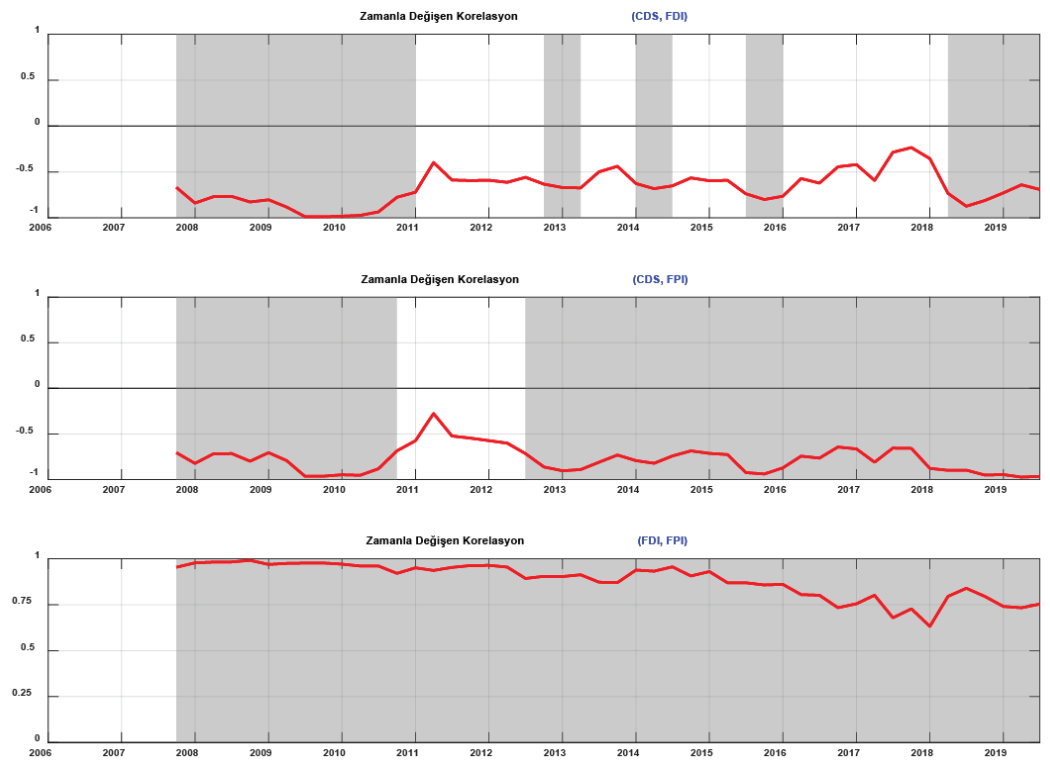

Not: Gri gölgeli alan \%10 düzeyinde istatistiksel olarak anlamllığı göstermektedir. Pencere uzunluğu (w) 8 çeyrektir. 
Șekil 2, değișkenler arasında sekiz çeyreklik periyotta geçerli zamanla değișen korelasyon ilișkisini içermektedir. Ilk iki panelde görüleceği üzere, DL_CDS ve DL_FPI ile DL_CDS ve DL_FDI değișkenleri arasında, literatüre paralel șekilde, zıt yönlü; en alttaki panele göre $\mathrm{DL}$ FPI ve DL_FDI değișkenleri arasında ise pozitif yönde geçerli ilișki elde edilmiștir. Ülke risk primindeki artıșla birlikte, hem doğrudan hem de porfföy yatırımlarında bir azalmanın gerçekleșmesi kaçınılmazdır. Son küresel finans krizi sonrası (2007 Ağustos - 2009 Mart) periyotta, ülke risk primi ile doğrudan yabancı yatııımlar arasında çok yüksek düzeyde (> -0.94) ve \%1 anlamlılık düzeyindeki negatif yönlü ilișki, yabancı yatırımların ülke risk primine ne kadar hassas olduğunu göstermektedir. Diğer bir ifadeyle, 200 puanın altında düșen CDS primi ile birlikte, 2009Q3'te 137,7 milyar \$ olan yabancı yatırım tutarı, 2010Q3'te 193 milyar \$ olmuștur. Benzer șekilde, yurtdıș yerleșiklerin portföy yatırım tutarı 88,3 milyar \$'dan 120,5 milyar \$'a yükselmiștir. Diğer taraftan, 2013 Mayıs döneminde FED tarafından yapılan genișlemeci politikanın (QE3) yıl sonunda bitirileceğine dair açıklama ile birlikte, tüm dünyada olduğu gibi Türkiye CDS primlerinde de artıș yașanmıș ve hem doğrudan hem de porfföy yatıım tutarlarında ciddi miktarlarda azalma meydana gelmiștir. 1 no'lu șekilde de görüleceği üzere, son yıllarda ABD-Türkiye cephesinde yașanan gerilimle birlikte CDS primleri, 2006 sonrası dönemde, 2019Q2'te en yüksek değere, 445,68, ulașırken, değișkenler arasında çok yüksek düzeyde zıt yönde ve \%10 anlamlılık düzeyinde bir korelasyon ilișkisine rastlanmıștır. Bu sonuçlar, yurtdıșı yerleșiklere ait yatırımların kriz dönemlerinde yani yurtdıșı ve yurtiçi gelișmelere șiddetli tepki verdiğini ortaya koymakładır.

\section{Sonuç}

Türkiye'de 1980'den sonra izlenen liberal politikalar kapsamında yabancı sermaye hareketleri önündeki engeller așamalı olarak kaldırılmaya bașlanmıștır. 1990 yılında TL'nin konvertibl olmasıyla birlikte sermaye hareketlerinin önündeki engeller tamamen kaldırıımıștır. 1990'dan sonra Türkiye'ye yapılan doğrudan sermaye yatıımları ve portföy yatırımlarında zamanla içinde artmaya bașlamıștır. Türkiye gibi gelișmekte olan ülkelere sermaye girișleri bir taraftan ekonomik aktiviteyi canlanırken diğer taraftan ciddi makroekonomik dalgalanmalara neden olmaktadır. Türkiye ve diğer gelișmekte olan ülke deneyimleri göstermiștir ki ülkeye sermaye girișlerinin tersine dönmesi ekonomi üzerinde ciddi etkiler yaratmakta hatta finansal krizlere neden olmaktadır. Bundan dolayı sermaye hareketlerini yönlendiren temel faktörleri anlamak önemlidir. 
Bu faktörler anlașılması ani sermaye çıkıșlarının istenmeyen sonuçlarının önlenmesine yardımcı olacaktır.

Bu çalıșmada da 2005Q4-2019Q3 periyodunda çeyreklik veriler kullanılarak CDS primleri ile yurtdıșı yerleșiklere ait doğrudan (FDI) ve portföy yatırımları (FPI) arasındaki ilișki incelenmiștir. Bu kapsamda çalıșmada kullanılan serilerin birim kök sınaması Fourier ADF birim kök testi kullanılarak yapılmıștır. Fourier ADF birim kök testi sonuncuna göre, düzey değerlerinde CDS serisi birim kök içerirken FDI ve FPI serileri ise durağan bulunmuștur. Serilerinin tamamını durağan hale getirmek için serilerin birinci farkları alınmıș ve farkı alınan serilerden CDS ve FDI serisi \% 1 önem düzeyinde, FPI ise \%5 önem düzeyinde duran hale gelmiștir. Fourier Granger Nedensellik testi ile seriler arasındaki ilișkilerin yönü belirlenmeye çalıșılmıștır. Elde edilen bulgulara göre FDI ile CDS primleri arasında, doğrudan yabancı yatırımlardan CDS primlerine doğru olmak üzere, tek yönlü nedensellik ilișkisi tespit edilmiștir. Bu sonuç, yurtdıșı yerleșiklere ait doğrudan yatırımlarında meydan gelen cari değișmelerin CDS primlerini etkileyeceğini göstermektedir. Diğer taraftan CDS ve FPI arasında ise çift yönlü nedensellik ilișkisi bulgusuna rastlanmıștır. Buna göre, CDS primlerinde meydana gelen değișmelerin portföy yatırımlarını etkileyeceğini; benzer șekilde portföy yatırımlarında meydan gelen değișimlerin de CDS primlerini etkileyeceğini söylemek mümkündür. Elde edilen sonuçlara göre, her iki değișkenin cari değerleri, diğerinin gelecekteki değerlerini tahmin etmede istatistiksel olarak faydalı bilgiler sunmaktadır. Ayrıca, değișkenler arasında literatürde elde edilen sonuçlara paralel, özellikle kriz sonrası dönemde çok yüksek seviyede anlamlı ancak zıt yönlü ilișkinin var olması, yurtdıșı yerleșiklerin CDS primlerindeki değișmelere ne kadar önem verdiğini ortaya koymaktadır.

Elde edilen test sonuçları, hem finansal hem de iktisadi istikrarın/büyümenin sağlanmasında, politika karar alıcılarına önemli bilgi sunmaktadır. Analiz sonuçları Türkiye ekonomisi için, CDS primleri ile yurtdıșı yerleșiklere ait yatırımlar arasında anlamlı ilișkinin var olduğunu göstermektedir. Ülkeye yapılacak yabancı yatırımları ve dolayısıyla milli geliri artırmak için, politika yapıcılarının ülke risk primlerini düșürmek için politikalar geliștirmesi gerektiğini ortaya koymaktadır. Ülke risk düzeyinin düșürülmesi için atılacak adımlarını kararlılıkla takip edilmesi, yurtiçi/yurtdıșı yatırımcılarının güvenlerini kaybettirecek uygulamalardan vazgeçilmesi ve en önemlisi de hukuk ve finansal istikrar alanında yapısal reformların yapılması gerekmektedir. 


\section{Kaynakça}

Aldasoro, I., \& Ehlers, T. (2018). The Credit Default Swap Market: What A Difference A Decade Makes. BIS Quarterly Review, June. https://www.bis.org/publ/ qtrpdf/r_qt1 806b.htm [Erișim Tarihi: 19.05.2020.

Alııntaș, N. \& Okuyan, H.A. (2019). CDS -Büyüme İlișkisi: Yeni Kırılgan Beșli Ülkeler Üzerine Bir Uygulama. II. International Symposium on Economics, Finance and Econometrics (Tam Metin Bildirisi, 246-252), Bandırma, Balıkesir.

Bașarır, C. \& Keten, M. (2016). Gelișmekte olan ülkelerin CDS primleri ile hisse senetleri ve döviz kurları arasındaki kointegrasyon ilișkisi. Mehmet Akif Ersoy Üniversitesi Sosyal Bilimler Enstitüsü Dergisi, 8(15), 369-380. doi:10.20875/sb.72076

Benghoul, M. (2019). Political Risk and Foreign Direct Investment in Tunisia: The Case of the Services Sector 2004-2016. International Journal of Sustainable Economies Management (IJSEM), 8(3), 48-60.

Caporale, G. M., Ali, F. M., Spagnolo, F. \& Spagnolo, N. (2017). International Portfolio Flows and Exchange Rate Volatility in Emerging Asian Markets. Journal of International Money and Finance, (76), 1-15.

Çonkar, M. K. \& Vergili, G. (2017). Kredi Temerrüt Swapları Ile Döviz Kurları Arasındaki Ilișki: Türkiye İçin Ampirik Bir Analiz. Ömer Halisdemir Üniversitesi İktisadi ve İdari Bilimler Fakültesi Dergisi, 10(4), 59-66. doi: 10.25287/ohuiibf.310704

Çulha, A. A. (2006). A Structural VAR Analysis of the Determinants of Capital Flows into Turkey. Central Bank Review, 2(2), 1 1-35.

Danacı, M.C., ȘiT, M., \& ȘiT, A. (2017). Kredi Temerrüt Swaplarının (CDS'lerin) Büyüme Oranıyla Ilișkilendirilmesi: Türkiye Örneği. Aksaray Üniversitesi İktisadi ve İdari Bilimler Fakültesi Dergisi, 9(2), 67-78.

Değirmenci, N. \& Pabuçcu, H. (2016). Borsa İstanbul Ve Risk Primi Arasındaki Etkileșim: Var ve NARX Model. Akademik Sosyal Araștırmalar Dergisi, 4(35), 248-261.

Egly, P. V., Johnk, D. W., \& Liston, D. P. (2010). Foreign porffolio investment inflows to the United States: The impact of investor risk aversion and US stock market performance. North American Journal of Finance and Banking Research, 4(4), 25.

Enders, W. \& Lee, J. (2012). A Unit Root Test Using a Fourier Series to Approximate Smooth Breaks. Oxford Bulletin of Economics and Statistics, 74(4), 574-599.

Enders, W., \& Jones, P. (2016). Grain Prices, Oil Prices, and Multiple Smooth Breaks in a VAR. Studies in Nonlinear Dynamics \& Econometrics, 20(4), 399-419.

Fung, H. G., Sierra, G. E., Yau, J. \& Zhang, G. (2008). Are The US Stock Market And Credit Default Swap Market Related? Evidence from the CDX Indices. The Journal of Alternative Investments, 11 (1), 43-61.

Ghosh, S. \& Herwadkar, S. (2009). Foreign Porffolio Flows and Their Impact on Financial Markets in India. Reserve Bank of India Occasional Papers, 30(3), 51-72.

Gokmenoglu, K., Kirikkaleli, D. \& Eren, B.M. (2019). Time and Frequency Domain Causality Testing: The Causal Linkage between FDI and Economic Risk for the Case of Turkey. The Journal of International Trade \& Economic Development, 28(6), 649667. doi: 10.1080/09638199.2018.1561745 
Hancı, G. (2014). Kredi Temerrüt Takasları ve BiST-100 Arasındaki Ilișkinin İncelenmesi. Maliye ve Finans Yazıları, (102), 9-22.

Ismailescu, I., \& Kazemi, H. (2010). The Reaction of Emerging Market Credit Default Swap Spreads to Sovereign Credit Rating Changes". Journal of Banking \& Finance, 34(12), 2861-2873. doi.org/10.1016/i.jbankfin.2010.05.014

Karahan, Ö., \& İpek, E. (2013). Türkiye'ye Yönelik Yabancı Sermaye Akımlarının Hacim ve Kompozisyonundaki Gelișmeler. Yönetim ve Ekonomi Araștırmaları Dergisi, 11 (21), 299-316. doi.org/10.11611/JMER215

Karluk, S. R. (2013). Uluslararası Ekonomi: Teori Politika. İstanbul: Beta Basın Yayın Dağıtım.

Norden, L. \& Weber, M. (2009). The Co-Movement of Credit Default Swap, Bond and Stock Markets: An Empirical Analysis. European Financial Management, 15(3), 529-562. doi: 10.1111/i.1468-036X.2007.00427.x

Sadeghzadeh, K. (2019). Borsa Endekslerinin Ülke Risklerine Duyarlılığı: Seçilmiș Ülkeler İçin Bir Panel Veri Analizi. Atatürk Üniversitesi İktisadi ve İdari Bilimler Dergisi, 33(2), 435-450.

Seyidoğlu, H. (2015). Uluslararası İktisat. Güzem Yayınları, 20. Baskı, İstanbul.

Yıldırım, H. H., \& Sakızcı, M. (2019). Portföy Yatırımları İle CDS Arasındaki İlișki: Türkiye Örneği. Social Sciences, 14(5), 2777-2792. doi: 10.29228/TurkishStudies.36938 
